without knowing it ; or, knowing it, they enjoy it. It is doubtful if, in the sterner, strenuous, and fiercely competitive days ahead-if they have not already arrived-we can much longer afford to neglect this vital matter of using even our leisure to the best purpose. At least greater opportunity for such could be afforded, and is within the range of practical politics.

The question of leisure occupation for those already in work, important as it is, almost fades into insignificance, however, beside the greater question of unemployment. So far as the programmes of the chief political parties have been revealed in view of the coming election, there does not appear to be anything refreshingly original or practically effective in contemplation to deal with this great evil ; and it is not, of course, pretended in this article that the suggestions herein tentatively offered contain anything very helpful by way of remedy or mitigation. It is, however, firmly believed that a vast field of employment could be opened up along the lines of land settlement, land reclamation, village industries, combined with industrial enterprise, possibly a programme somewhat similar to that adopted for the Greek refugees.

It is not possible here to go fully into this part of the subject, except to say that the land interestallotment, small holding, or the like--could be more effectively provided in garden cities, industrial villages, and so forth, where new industries could be established, than in or near existing industrial centres where little or no land is available. In any event, the new derating concessions should be a great help in establishing industrial small holdings; and the extent to which such holdings are already used by those engaged in other occupations is revealed by a recent study of small-holding economics in one county alone, for example, Carmarthen. Nearly fifty per cent of all holdings under fifty acres are occupied by persons with nonagricultural employments, representing nearly every trade and profession; miners, general labourers, carpenters, butchers, and grocers being the chief. We are glad to know in this connexion that in some districts in South Wales, where allotments have gone out of cultivation on account of inability to pay rent for them, or purchase seeds or manures, the Society of Friends is successfully reviving allotment holdings and providing facilities for unemployed miners to work them for the production of food. There could be no better use for grants from the Central Coalfields Distress Fund, in suitable districts, than to encourage work on the land in this way.

No. 3097, VoL. 123]

\section{Reform of the British Patent System.}

T $T$ is clear from statements which have been made 1 in the House of Commons during the past few months that a serious state of affairs exists at the Patent Office. On July 18, 1928, Mr. Herbert Williams stated, in answer to a question, that 6300 complete specifications were awaiting first action by the examiner and that these arrears were accumulating at the rate of 67 per week. On Feb. 26 last, in answer to a further question, he stated that the arrears now amounted to 8400 complete specifications and were increasing at the rate of 76 per week. Since about 20,000 complete specifications are filed annually, the work is therefore just over five months in arrear on the average.

Figures given by Mr. Williams in July indicate that while the number of specifications to be dealt with annually had increased by 26 per cent as compared with 1912, the strength of the examining staff had decreased by 10 per cent. This economy, at a time when the Patent Office obtains a large and increasing surplus of fees over expenditure, appears to be most unjustifiable. The present critical state of affairs could have been foreseen and provided against some years ago, for the input of patent applications has been steadily increasing since patent business became normal after the War. The public has a right to know why such steps were not taken in good time. Did the Comptroller of the Patent Office fail to warn the Minister or did the Minister fail to heed his warnings? Or is it that, as in the case of certain other technical departments, there is interposed between the Minister and the technical chief a body of administrative officials who fail to appreciate technical requirements?

Last October an important report on the reforms which are needed in the British patent system was published by the British Science Guild. This report met with an enthusiastic reception from the financial, technical, and daily press, and we understand that it has received the formal support of a number of important bodies. Asked whether the Board of Trade proposed to take any action in this connexion, Mr. Herbert Williams stated on Feb. 26 that the President of the Board proposed to set up a committee in due course to review existing patent law and practice.

While the British Science Guild Committee may be congratulated on this promise of a result arising from its labours, some disappointment will be felt at the absence of any indication that the matter will be carried through expeditiously. 